\title{
Legal Transplants and the Frontiers of Legal Knowledge
}

\begin{abstract}
Michele Graziadei*
The study of legal transplants provides a vital critical supplement to mainstream theories about legal change. Legal transplants are not exceptional or isolated occurrences, despite the economic, social, political and cultural barriers that separate the world's legal systems. This Article goes beyond traditional approaches to the study of transplants by substituting the figurative language of transplants with explicit theory about how legal change is produced. It first provides a brief account of what the literature on legal transplants has achieved so far in terms of "macro" explanations of legal change currently available. It then argues that legal transplants as social acts performed by individuals call for a study of the "micro" level of engagement with legal change by individuals. The key notion that is advanced to explore this dimension is the notion of mediated action, which denotes action that is performed by individuals making use of features of the environment as tools to interact in a specific setting. The notion of mediated action was first introduced in cultural-historical psychological investigations of the social formation of the mind. As social acts, legal transplants represent instances of mediated action. The last part of this Article highlights how legal transplants raise questions of justice and discusses briefly how the new approach to the study of transplants advocated here relates to them.
\end{abstract}

* The author wishes to thank Joshua Getzler, Ron Harris, Nir Kedar, Roy Kreitner, Celia Wasserstein Fassberg, and all the participants at the conference on Histories of Legal Transplantations for their very helpful observations and comments. The usual disclaimer applies. 


\section{INTRODUCTION}

Like every other discipline, legal history is becoming more and more cosmopolitan nowadays. This turn towards the study of the historical relationships among the world's legal systems is supported by comparative law studies. The ever-growing literature on legal transplants is a resource for legal historians interested in legal change with reference to the transnational dimensions of the law. Legal historians who have not taken a strong interest in comparative law may nonetheless still ask what the study of legal transplants has to offer.

A first answer to the question could simply be that legal change under the influence of exogenous factors deserves attention in its own right. It is neither an exceptional nor a rare phenomenon, despite all assertions to the contrary. Even the occasional study exploring a specific legal transplant has its merit, to the extent that it casts light on how external factors contribute to the making of local law. Legal transplants are surely of interest to those who are interested in the study of relations of power, such as those arising through colonization (and the fate of transplants tells us much about the postcolonial landscape). By now, it should be clear that this field of study encompasses more than just the possibility of developing occasional descriptions of "transplants" that have occurred in the past, or are happening today. Each case is an invitation to explore what lies behind the metaphor of "transplants." The crucial question for historical and comparative research today therefore concerns what the student of "legal transplants" can turn up once the figurative language of transplants is substituted with explicit theory about how legal change occurs. In other words, once we know, following Tushnet (who himself follows Lévi-Strauss), that bricolage occurs in the law as well and that the bricoleurs have been at work here and there, ${ }^{1}$ what other lessons can one learn by studying legal transplants?

My argument is that the study of legal transplants may be helpful to developing more interesting models of how the law changes than those

1 Mark Tushnet, The Possibilities of Comparative Constitutional Law, 108 YALE L.J. 1225, 1229 (1999): "Contemporary references to comparative constitutional materials may be a form of bricolage. Functionalists and expressivists worry about whether appropriating selected portions of other constitutional traditions is sensible, or whether the appropriation will 'work' in some sense. The bricoleur does not have these concerns about maintaining proper borders among systems." On this point, the author refers the reader to Claude LÉvi-StRauss, THE SAVAGE Mind 16-17 (John Weightman \& Doreen Weightman trans., 1966). 
currently available from a mainstream point of view. I would also argue that the study of this subject broadens our understanding of crucial aspects of the law, including those that raise questions of justice. In advancing these general propositions, I am addressing points that have already been covered by others, to whom I am obviously indebted. But previous contributions on the topic have not touched upon some aspects of it that still need to be addressed.

To tackle the questions raised above, I will first provide a brief account of what the literature on legal transplants has achieved so far. ${ }^{2}$ I will then show why further progress in the field requires the development of a clearer picture of what prompts individual action leading to a transplant. In that sense, what I propose to add to the "macro" explanations of legal change currently available is an analysis of the "micro" level of individual action which is implicated in the transplant. To be sure, I would be the last one to deny that macro approaches framed in terms of institutional action advance powerful explanations of transplants as means of change, and I do not believe that minimalism is a virtue. Yet a closer look at what happens at the micro level of individual interactions can be instructive too. If there is to be a micro history of transplants, let there be a theory of it as well. ${ }^{3}$

This "micro" dimension relating to the interface between thought formation and social action is best approached by opening up the inquiry to the contributions of other disciplines. In that sense, this is an Article on the frontiers of legal knowledge, i.e., on the porous boundaries of legal knowledge and on the shortcomings of our current understanding of how legal change unfolds. Lastly, the study of legal transplants from this perspective raises questions of justice too. When the framework of a legal transplant undermines legality as a dialogic exercise, in which all have the right to participate on an equal footing, justice is called into question. Some of the most burning questions of justice in the contemporary world are inscribed in this scenario. The last part of this Article therefore highlights how legal transplants raise questions of justice and discusses briefly how the micro approach advocated here relates to them.

2 For further reflections: Michele Graziadei, Comparative Law as the Study of Transplants and Receptions, in THE OXFORD HANDBOOK OF COMPARATIVE LAW 441 (Mathias Reimann \& Reinhard Zimmermann eds., 2007).

3 At least if law is to be understood not as a self-contained system, but as an aspect of social life: William J. Novak, Law, Capitalism, and the Liberal State: The Historical Sociology of James Willard Hurst, 18 LAW \& HIST. REV. 97 (2000). 


\section{The Evolution OF THE Literature on Legal Transplants: A Periodization}

A periodization of the literature on legal transplants should start with those contributions that were produced avant la lettre, before legal transplants became a topic in their own right. Historically, the reception of Roman law in medieval Europe raised the problem - explicitly addressed by Montesquieu ${ }^{4}$ - of the fit between local conditions and imported law. Similarly, the expansion of the common law during the colonial period, the diffusion of Islamic law in many countries, and the reception of Western codes and constitutional models across the world have hardly gone unnoticed in the last two hundred years. The literature on legal transplants avant la lettre includes a first layer of contributions, which investigate these or similar phenomena. The reception of foreign laws, or the outright imposition of foreign laws through colonization or conquest, have always generated reflections on the tension between the local and the foreign elements of the law.

The literature that puts an emphasis on legal transplants as a major factor of change in comparative and legal history circles is not made up of this first layer of works, however. It consists instead of essays that, in the last forty years, reacted to functionalist-positivist views of the law, which consider the law as a constellation of norms produced by ruling powers in response to society's needs, backed up by the application of force. Research on legal transplants has been used to challenge this account of the law by accumulating evidence to show how much law is borrowed or transplanted, instead of being created through local innovations developed on the basis of local conditions. ${ }^{5}$ For example, the fact that the Japanese civil code bears a

4 Charles de Secondat, Baron de Montesquieu, The Spirit of the LaWs bk. I, ch. 3, at 7 (Thomas Nugent trans., 4th ed. 1766). The influence of Montesquieu on Savigny is obvious. Both thought that the law is organically related to the constitution of society. On Montesquieu's stance, see Robert Launay, Montesquieu: The Specter of Despotism and the Origins of Comparative Law, in RETHINKING THE MASTERS OF COMPARATIVE LAW 22 (Annelise Riles ed., 2001); and for his influence on Savigny: Peter Stein, Legal Evolution 56 passim (1980).

5 The contribution by Alan Watson, Legal Transplants: An ApProach to COMPARATIVE LAW (1974) is the first of this kind to have gained immediate resonance, in part because it attracted criticism from many quarters. The argument presented in this slim volume was further advanced in several other publications by the same author, which cannot be cited here in full. See, e.g., ALAN WATSON, LEGAL 
close resemblance to the German civil code, with occasional concessions to the French civil code, cannot be explained by positing a fundamental commonality in terms of socioeconomic and cultural factors between France, Germany and Japan. It is to be explained otherwise, i.e., by the Japanese government's choice to rely on these Western models to change the law of Japan. In this special sense only, borrowed law relates to the local conditions, which in truth are often the conditions of an imagined future. ${ }^{6}$

The literature on transplants received widespread attention among comparativists because it showed that legal systems can accommodate a plurality of models, though most transplants probably still occur across legal systems that already have much in common. Though only some legal systems are currently classified as "mixed," many more exhibit features revealing that borrowing or transplantation are regular occurrences, even across boundaries that would not have seemed to be so permeable. This finding casts serious doubts on the utility of the established approach to comparative law with its heavy reliance on the classification of legal systems into legal families. The dynamic approach to comparative law supported by the study of legal transplants thus stands in stark contrast to the static picture of legal families portrayed by classics like René David's Major Legal Systems in the World. ${ }^{7}$

In more recent years, the literature on legal transplants has commanded growing attention for different reasons, which are not purely academic. If the law can be transplanted, policymaking by governing powers and international institutions can achieve objectives that require legal reform through legal transplants. The question whether law can be transferred from one place to another turns out to be a question of the highest importance, whether these actors are interested in political reform, economic growth,

Origins and Legal Change (1991); Alan Watson, Comparative LaW: LaW, REALITY AND SOCIETY (2007). There is now a vast bibliography on legal transplants that explores the topic from different perspectives. For a critical perspective on the topic, see, for example, Duncan Kennedy, Three Globalizations of Law and Legal Thought, in THE New LAW AND ECONOMIC DEVElopment 19 (David M. Trubek \& Alvaro Santos eds., 2006); Diego EduARdo LóPeZ Medina, TeOría IMPURA DEL DERECHO (2004); Pier Giuseppe Monateri, The 'Weak Law': Contaminations and Legal Cultures (Borrowing of Legal and Political Forms), 13 TRANSNAT'L L. \& CONTEMP. PRoBs. 575 (2003).

6 David Nelken, Comparatists and Transferability, in COMPARATIVE LEGAL STUDIES 446, 457 passim (Pierre Legrand \& Roderick Munday eds., 2003).

7 RENÉ DAVID \& JOHN E.C. BRIERLEY, MAJOR LEGAL SYSTEMS IN THE WORLD TODAY (1978). Cf. Rodolfo Sacco, Legal Formants: A Dynamic Approach to Comparative Law (pts. 1 \& 2), 39 AM. J. COMP. L. 1, 343 (1991). 
social progress, or less beneficial ends. Unsurprisingly, institutions like the World Bank now take an interest in the literature on legal transplants and the topic features regularly in the study of economic growth and political change, as every student of law and development knows. ${ }^{8}$

Once the topic was established as a new academic subject, the literature on legal transplants entered a third stage. This is marked by the critical discussion of the thesis arguing that legal transplants are not isolated occurrences, but regular factors of change, notwithstanding the economic, social, political and cultural barriers that separate the world's legal systems. It is hardly surprising that comparative law studies on transplants soon became the target of criticism by authors who supported the study of law in functional terms. ${ }^{9}$ They were meant to provoke this reaction. As a matter of fact, the second layer of research on transplants just mentioned represented a clean break with the orthodoxy which has held, at least since the time of Montesquieu, that law and society are bound up together. Yet the finding that law is mobile has also been criticized from a different standpoint, on the basis of the assumption that law as a social construct cannot remain the same, once it is dislocated. ${ }^{10}$ On this account, the "transplant" cannot survive the change of context. In the new context, the original meaning of what is transplanted is, of necessity, lost. From this point of view, legal transplants are held to be impossible. This strong criticism - which is based on hermeneutics is not the last word on the subject, however. Its rejection of any mechanical view of the transplantation process opened up the field to more nuanced contributions. These aimed to show how transplants always involve a degree of cultural adaptation, a "domestication" that is the necessary counterpart of

8 On these issues: The New Law AND Economic Development, supra note 5; Symposium, Diffusion of Law in the 21st Century: Interaction and Influence, 47 HARV. INT'L L.J. 489 passim (2006) (contributions by Pierre Legrand, William Twining, David A. Westbrook); John Braithwaite \& Peter Drahos, Global Business Regulation (2000); see also CurTis J. Milhaupt \& KATHARINA Pistor, LAW AND CAPITALISM: What CORPORATE CRISES REVEAL ABOUT LEgal SySTEMS AND ECONOMIC Development AROUND THE WORLD (2008). Needless to say, globalization depends upon this dynamic: Transnational Legal Processes: GLOBALISATION AND POWER DISPARITIES (Michael Likosky ed., 2002).

9 See, e.g., Richard L. Abel, Law as Lag: Inertia as a Social Theory of Law, 80 Mich. L. ReV. 785 (1982) (reviewing Alan Watson, Society AND Legal Change (1977)).

10 See Pierre Legrand, The Impossibility of 'Legal Transplants,' 4 MAASTRICHT J. Eur. \& COMP. L. 111 (1997); Pierre Legrand, The Same and the Different, in COMPARATIVE LEGAL STUdIES, supra note 6, at 240. 
the transplantation - whether it concerns the law, or other social or cultural artifacts that travel across space. ${ }^{11}$

Meanwhile, anthropological and sociological studies have highlighted the complex constitution of "culture" and "society," i.e., those entities which feature so prominently in any discourse about the social constitution of the law. Far from being a homogeneous whole, culture is itself the expression of tensions and compromises among different possible cultural constellations. ${ }^{12}$ Comparative law itself has established that the undifferentiated notion of "law" is quite unhelpful in this type of inquiry. The various components of legal systems - the different formants in Sacco's terminology — may fall under the effects of different influences. ${ }^{13}$ Hence the necessity to distinguish which features of legal systems come into consideration in the analysis of transplants. A concrete example of this type of analysis is Nir Kedar's recent study of the Israeli legal system as a mixed jurisdiction in a double sense, ${ }^{14}$ not only because it exhibits the mixing of Anglo-American and Romano-Germanic legal institutions, but also because it shows the working of institutions that originated in Anglo-American law within the framework of a European political culture. We have to turn to this culture to understand why the codification of the Israeli civil law is considered to be a key factor in the development of the Israeli legal system. ${ }^{15}$

That is where we stand today with regard to the methodological issues discussed by the literature on legal transplants. Considering this picture from a critical point of view, it is only fair to say that all the approaches to legal transplants so far considered have essentially focused on law as a cultural or social object with institutional dimensions. I fully agree with this approach, insofar it includes in the constitution of law all those habits that have a collective dimension and normative force. But I would also argue that

11 See, e.g., AdAPting Legal Cultures (David Nelken \& Johannes Fest eds., 2001).

12 See now Annelise Riles, Comparative Law and Socio-Legal Studies, in THE OXFORD HANDBOOK OF COMPARATIVE LAW, supra note 2, at 775; Roger Cotterell, Comparative Law and Legal Culture, in THE OXFORD HANDBOOK OF COMPARATIVE LAW, supra note 2, at 709; FREDRIK BARTH, ETHNIC GROUPS \& BOUNDARIES (1969).

13 Sacco, supra note 7: Sacco has been one of the pioneers of the research on legal transplants among comparativists.

14 Nir Kedar, Law, Culture and Civil Codification in a Mixed Legal System, 17 CAN. J.L. \& SOC'Y 177 (2007).

15 Alfredo Mordechai Rabello \& Pablo Lerner, The Project of The Israeli Civil Code: The Dilemma of Enacting a Code in a Mixed Jurisdiction, in LIBER AMICORUM Guido AlPa: Private LaW Beyond the NATIONAL Systems 773 (Mads Andenas et al. eds., 2007). 
the literature on legal transplants is far less informative on how individual agency works to produce legal change.

Legal transplants as social acts performed by individuals deserve a second look. ${ }^{16}$ They deserve a second look even when the intuitive explanation for the transplant - its alleged "functionality" — is wholly plausible. ${ }^{17}$ In this Article, therefore, I intend to unearth what lies beyond the macro level of "the law," to highlight the micro dimensions of individual interactions which are implicated in the transplant. An analysis of the features of the process whereby an individual is prompted to take action leading to a transplant is as important as a reflection on the intrinsic quality of the law that is at stake, or the fit between that law and the local context, as Michael Crystal and Ron Harris show in their contribution on the transplantation of British company law in post-Ottoman Palestine. ${ }^{18}$ Furthermore, though the trajectories of the lives of the protagonists of transplants remains a fascinating subject, the shift advocated here clearly goes beyond the biographical dimensions related to transplants, which have so often been investigated in the study of legal transplants.

16 In the same vein, see Assaf Likhovski, Argonauts of the Eastern Mediterranean: Legal Transplants and Signaling, 10 THEORETICAL INQUIRIES L. 619 (2009).

17 Since the nineteenth century at least, this is the standard answer to the question why transplants (not imposed by violence) occur: RUDOLF VON JHERING, GEIST DES RÖMISCHEN RECHTS AUF DEN VERSCHIEDENEN STUFEN SEINER ENTWICKLUNG pt. I, at 8 (B. Schwabe 9th ed. 1955), cited in KonRAD ZwEIGERT \& HEIN KÖTZ, INTRODUCTION TO COMPARATIVE LAW 17 (Tony Weir trans., 3d rev. ed. 1998): "The reception of foreign legal institutions is not a matter of nationality, but of usefulness and need. No one bothers to fetch a thing from afar when he has one as good or better at home, but only a fool would refuse quinine just because it didn't grow in his back garden." See also Ugo Mattei, Efficiency in Legal Transplants: An Essay in Comparative Law and Economics, 14 INT'L REV. L. \& ECON. 3 (1994), and on the same point, in different perspective: Ugo Mattei, A Theory of Imperial Law: A Study on U.S. Hegemony and the Latin Resistance, 10 IND. J. GLOBAL LEGAL STUD. 383 (2002).

18 Ron Harris \& Michael Crystal, Some Reflections on the Transplantation of British Company Law in Post-Ottoman Palestine, 10 THEORETICAL INQUIRIES L. 561 (2009). This is also a point made at the macro level in the debate over the so-called "legal origins hypothesis": $C f$. Daniel Berkowitz et al., Economic Development, Legality, and the Transplant Effect, 47 EUR. ECON. REV. 165 (2003). 


\section{But What Is a Transplant? Multiple Perspectives About Transplants AND HOW TO LIVE WITH THEM}

Let me introduce the topic by addressing a preliminary point. The literature on legal transplants abounds with terminological distinctions. ${ }^{19}$ Their profusion reflects both every scholar's desire to leave a footprint in the field and the difficulty of including all the different events that make up the historical record in a single framework.

By itself, this terminological fragmentation suggests that identifying what a transplant is can be a tricky matter. For instance, agents of change that had no intention of borrowing foreign law as such may have carried out what later commentators would call a transplant. Quite often, the intent of these agents was simply to make the (local) law evolve in the light of seminal ideas, or of an enlightening experience, etc. Could they, just like Molière's Bourgeois gentilhomme, who spoke prose without knowing it, have been engaged in making transplants without knowing it? On the other hand, some transplants exist only in the beliefs of a certain community. This paradoxical possibility arises because the collective memory of a certain group can be at odds with the historical facts. ${ }^{20}$ Demonstrating this possibility, Pnina Lahav's contribution on the history of the American influence on Israeli legal education shows that the problem method of legal education in Israel was not an import from Harvard, as many today think, but was instead an innovation originally promoted by Professor Joshua Weisman. Hence, this is "an excellent example of the need to address transplantation carefully and skeptically. Something that looks like a transplant may, in fact, be homegrown."21

Confronted with these patterns, the question then is: who shall pass judgment on what is a transplant? I would argue that the possibility of a plurality of answers to the question remains open. One need not be a

19 For an illustration of some of these distinctions, see Graziadei, supra note 2, at 443-44.

20 The seminal contributions on this point are THE INVENTION OF TRADITION (Eric Hobsbawm \& Terence Ranger eds., 1983); and MAURICE HalbWACHS, ON Collective Memory (Lewis A. Coser trans., 1992).

21 Pnina Lahav, American Moment[s]: When, How, and Why Did Israeli Law Faculties Come to Resemble Elite U.S. Law Schools, 10 THEORETICAL INQUIRIES L. 653, 674 (2009). 
relativist to appreciate that the same historical events can be approached from different perspectives. ${ }^{22}$

It is well known that one of the most delicate problems in historiography is to what extent it is possible to avoid anachronism in dealing with the past. To what extent, for example, does it make sense to use the concept of "feudalism," which was coined after the fact, and originally colored with a pejorative connotation, ${ }^{23}$ to write the history of pre-modern Europe? There is no single correct answer to this question. All one can ask for is that the premises underpinning the research be made explicit. This will help to understand its limits.

Comparative law tackles similar problems, especially when it deals with institutions that are unknown in one or more legal systems. How can the English law of trusts be explained to a French or Italian lawyer who knows nothing about the distinction between common law and equity? Should such an explanation illustrate the peculiar learning of equity lawyers, and if so how? And in which sense does that distinction have an operative edge in England today? Should we speak of a transplant in the presence of selective imitation, such as that which occurs when a civil law country enacts legislation reproducing only some features of trusts as known, for example, in England?

Any serious comparative law study requires an analysis of the concepts and categories that have gained currency in the community which is being studied. But this analysis is carried out in the light of an external point of view, that of the comparativist. The elaboration of that point of view usually involves concepts and categories that are at least in part autonomous from those adopted locally. They may not be known or shared by the members of the community in question. Comparative law embraced the functional method in order to develop such concepts and categories. ${ }^{24}$ Yet it never set forth systematically, in formal terms, the distinction between all these various perspectives. Because of the search for objectivity in the law in comparative law - the problem of representing the multiplicity of points

22 Carlo Ginzburg, Distance and Perspective: Two Metaphors, in Wooden Eyes 139 (Martin Ryle \& Kate Soper trans., 2001).

23 Cf. Amalia Kessler, Deciding Against Conciliation: The Nineteenth-Century Rejection of a European Transplant and the Rise of a Distinctively American Ideal of Adversarial Adjudication, 10 THEORETICAL INQUIRIES L. 423 (2009).

24 Cf. Ralf Michaels, The Functional Method of Comparative Law, in THE OXFORD HANDBOOK OF COMPARATIVE LAW, supra note 2, at 339; Michele Graziadei, The Functional Heritage, in COMPARATIVE LEGAL STUDIES, supra note 6, at 100. 
of view that emerge through the comparative exercise has too often been belittled. ${ }^{25}$

The problem in question is, on the other hand, well known to anthropologists. In anthropology, the pair of neologisms emic/etic refer, respectively, to distinctions that are meaningful to the members of a certain community and can be validated only by them (emic), and to extrinsic concepts or categories adopted by the observers of that community (etic). These neologisms were introduced into the subject by analogy to the terms "phonemic" and "phonetic," first used by linguists to denote different levels of description of the sounds of a language. ${ }^{26}$

Comparative law studies can benefit from an increased awareness of the necessity to distinguish between the different perspectives involved in the study of transplants. All too often those who point to legal transplants as a means by which legal change is produced are confronted with the reply that the only real choice here is between rejection and assimilation. This retort assumes that something foreign cannot really "fit in," unless it is completely assimilated. Until then, what is borrowed works as an irritant. ${ }^{27}$ But once assimilation has been achieved, the foreign element is no longer apparent, it is gone as a transplant. Before buying this reconstruction of transplants, let's examine it critically.

First, since transplants are regular occurrences in the development of the law, it is difficult to see why they should be considered somewhat artificial, or exceptional. Second, the time frame adopted to evaluate the consequences of a specific event is relevant. The passage of time alters the original situation; over time, nothing remains the same. What is the proper time frame to pass judgment on whether something foreign really "fits in" the local ambience? Should we think in terms of months, years, decades, centuries? True, at the end of a transplantation process it may be necessary - so to speak - to throw away the ladder that was so helpful to reaching the top. ${ }^{28}$ The transplant thus becomes invisible. Nonetheless, to stick to the metaphor, an outside observer will still notice that the ladder had to have been there in the first place, whether its users do not have any memory of it, or are unwilling to mention it, or do not consider it an important element in the context. An entire community may be unwilling to be open about the foreign origins of cultural

$25 C f$. Pierre Legrand, Comparative Legal Studies and the Matter of Authenticity, $1 \mathrm{~J}$. CoMP. L. 365 (2006).

26 EMICS AND ETICS (Thomas N. Headland et al. eds., 1990).

27 On this metaphor: Gunther Teubner, Legal Irritants: Good Faith in British Law or How Unifying Law Ends Up in New Differences, 61 M.L.R. 11 (1998).

28 Ludwig WitTGenstein, Tractatus Logico-Philosophicus $§ 6.54$ (1921). 
elements that are now considered constitutive of the collective identity shared by the members of that community. This does not mean that something alien was not there in the first place. It may be impolite to raise the question, and yet answers to impolite questions can be very instructive indeed.

The increased attention paid in recent years by comparative law scholarship to the linguistic interactions involved in legal transplants and to legal translation is, perhaps, also a response to the necessity of developing a better appreciation of the multiplicity of perspectives involved in legal transplants. An account of a transplant by the members of the community that experimented with it does not necessarily correspond to the outsider's account of the same historical fact. It is not framed in the same language, to begin with. ${ }^{29}$

\section{MACro-Micro I: LANGUAGE AND TOOLS}

It is one thing to notice that legal transplants happen. But to have an inkling of what goes on when they happen is quite another. It is virtually impossible to make sense of legal transplants without inquiring what legal change implies in empirical terms, i.e., in terms of empirical analysis of the social acts involved in the actuation of transplants by individuals.

From this perspective, mainstream legal analysis is not the best available framework to understand legal change. I am considering here the conventional analysis of legal change, which roughly corresponds to a view of the legal system that often represents the authority of the law by a model in which norms are imposed from above, through a top-down chain of command. This model implicitly holds that language is a transparent means of communication and will only occasionally fail to convey the necessary information to those who are subject to the law. Under this model, legal change is essentially a matter of sovereign will and of sovereign power. It is hardly surprising that, in the history of ideas, as well as in practice, the most serious challenge to this reconstruction of the legal system has been carried

29 On comparative law, language and legal translation, the studies that are contributing to the renovation of the field include at least: JEAN-CLAUDE GÉmAR \& NiCHOLAS Kasirer, JuRILINGUistics: Between LaW AND LANGUAGE (2005); Pierre Legrand, Issues in the Translatability of Law, in NATION, LANGUAGE, AND THE ETHICS OF TRANSLATION 30 (Sandra Bermann \& Michael Wood eds., 2005); Bernard Grossfeld, Comparatists and Languages, in COMPARATIVE Legal STUDIES, supra note 6, at 154; Rodolfo Sacco, Lingua e Diritto, 2000 ARS INTERPRETANDI 113; and ICHIRO KitAMURA, PROBLEMS OF THE TRANSLATION OF LAW IN JAPAN (1993). 
out in the name of custom. Customary law works without a sovereign who is able to express a will and without putting great faith in words. Nor it is surprising that, in light of the limitations of this monistic model, theories of law which speak of legal pluralism have attained prominence today. ${ }^{30}$

The dominant "macro" view of the legal system mentioned above veils the problems that law, especially transplanted law, poses as a normative order. Legal change on a grand scale surely can be brought about by decision-making located in centers of power. Over the centuries, ruling powers have been able to prove this beyond a reasonable doubt. But when the focus is on change at the level of individual interactions the historical record is not self-explanatory, even when the politics and power relations which drive the process of change are crystal clear.

An account of the production of legal innovation at this level, i.e., at the level of engagement with legal change by individuals, must unveil the structure of individual action. ${ }^{31}$ Individual action is conceived and then actuated through verbal and nonverbal behavior. Both are constitutive of the institutional dimensions of the law resulting from the collective effects of individual actions. In literate societies it is easy to overestimate the importance of the linguistic formulation of norms, but comparative law (along with legal sociology) confirms that language itself floats on a sea of implicit knowledge and understanding. The concept of cryptotype introduced by Sacco among comparativists stands for these silent dimensions of the law, ${ }^{32}$ which represent the classic nine-tenths of the iceberg below the water line. ${ }^{33}$ At a more general level, the study of culture shows indeed that language is just one of many tools that humans employ. ${ }^{34}$

30 For the present debate over the various conceptions of legal pluralism, see the contributions collected in ÉTUDIER ET ENSEIGNER LE DROIT 318 passim (Nicholas Kasirer ed., 2006); and in 9 THEORETICAL INQUIRIES L. 343 passim (2008).

31 This is also, in my view, the starting point of the radical version of pluralism advanced by Roderick A. Macdonald, Here, There . . and Everywhere: Theorizing Legal Pluralism; Theorizing Jacques Vanderlinden, in ÉTUDIER ET ENSEIGNER LE DROIT, supra note 30, at 318 passim; and by Jacques Vanderlinden, Return to Legal Pluralism: Twenty Years Later, 28 J. Legal PluRALISM \& UnOfFicial L. 149 (1989).

32 Cf. Sacco, supra note 7, at 343, 347-48. The author borrowed this notion from the linguist Benjamin LeE Whorf, Language, Thought And Reality 70 (1956). In the same vein: Edward Eberle \& Bernhard Grossfeld, Patterns of Order in Comparative Law: Discovering and Decoding Invisible Powers, 38 TEX. INT'L L.J. 291 (2003).

33 Cf. Stewart Macaulay, Contracts, New Legal Realism, and Improving the Navigation of the Yellow Submarine, 80 Tulane L. REV. 1161 (2006).

34 Imitation not mediated by words is, of course, the way in which cultural innovation 
This insight can be further elaborated by taking into account the results of research on mediated action, which was first carried out by cultural-historical psychology in the last century. Mediated action denotes action that is performed by individuals making use of features of the environment as tools to interact in a specific setting. The pioneer in this field was the Soviet psychologist Lev Vygotsky, who investigated the social formation of the mind..$^{35}$ A contemporary of Jean Piaget, with whom he had much in common, beginning with rejection of the Cartesian mind-body dualism, Vygotsky underscored the importance of mediated action in the constitution of human psychology. Cole and Wertsch summarize his theory as follows:

Higher mental functions are, by definition, culturally mediated; they involve not a "direct" action on the world, but an indirect action, one that takes a bit of material matter used previously and incorporates it as an aspect of action. In so far as that matter has itself been shaped by prior human practice (e.g., it is an artefact), current action benefits from the mental work that produced the particular form of that matter. ${ }^{36}$

A graphic illustration of mediated action is provided by the following experiment. Vygotsky and his collaborators asked a patient with Parkinson's disease to walk across the room where they were conducting their research. The patient did not move; the request produced only an increase of his tremors. Before repeating the request, they placed pieces of paper on the floor marking a sequence of steps. When they asked the patient once more to walk, he crossed the room by treading sequentially on the pieces of papers. They worked as cues telling him what to do: they made a difference. ${ }^{37}$

The idea of mediated action is not limited to the hypothesis of action realized through the instrumentality of material tools. Language features prominently among the artifacts considered by Vygotsky, along with "various systems for counting; mnemonic techniques; algebraic symbol systems; works of art; writing; schemes, diagrams, maps, and mechanical drawings; all sorts of conventional signs, and so on." 38

Vygotsky made it clear that the way the tool is actually used may or may

spreads in the animal world. $C f$. Thomas R. Zentall, Imitation: Definitions, Evidence, and Mechanisms, 9 ANIMAL COGNITION 335 (2006).

35 For an introduction to his thought: THE CAMBRIDGE COMPANION TO VyGOTSKY (Harry Daniels et al. eds., 2007); Piaget-Vygotsky: The Social Genesis of THOUGHT (Anastasia Tryphon \& J. Jacques Vonèche eds., 1996).

36 Michael Cole \& James V. Wertsch, Beyond the Individual-Social Antinomy in Discussions of Piaget and Vygotsky, 39 HuM. DEV. 250, 252 (1996).

37 JAMES V. WeRTSCH, VygOtSKY AND THE SOCIAL FoRMATION OF Mind 78 (1985).

38 Lev Semënovich Vygotsky, The Instrumental Method in Psychology, in THE 
not correspond to its intended use. We can use a broom to feign riding a horse, though this use is surely not its intended use. This is why his theory focused on mediated action, rather than on the tool itself, or its intended use. The blurring of the distinction between the internal and the external sphere which occurs when tools are used and the human ability to internalize tools are a central feature of human psychology under this theory. Vygotsky actually maintained that it is the central tenet of human psychology.

Drawing upon the insight that language is a social tool, the same approach provides an account of how cultural processes unfold in "sites of engagement," where discourses turn into action..$^{39}$ Mediated discourse analysis rejects the sender-receiver model of communication precisely because that model ignores the social setting in which actions of all kinds take place:

[A] text never leads to any unique outcome or action and so a fortiori an analysis of that text remains at an even greater distance from social action: No analysis of a text in itself . . . can ever determine whether a news story might be appropriated to form a portion of an argument among friends over a coffee, be used as an example in a university lecture on critical discourse analysis, or that the entire newspaper may be used to wrap fish in the market. ${ }^{40}$

As social acts, legal transplants represent instances of mediated action. The tools employed in carrying out the transplants are constituted by the original legal materials appropriated to do so. Without those tools, the course of legal change would have been different, and yet what the transplant achieves is no mere reproduction of an original form or content.

In this volume, the article by Yoram Shachar on the drafting of the Israeli Declaration of Independence ${ }^{41}$ brilliantly illustrates how mediated action works with respect to legal transplants. The task of preparing a first

Concept of Activity in Soviet Psychology 134, 137 (James V. Wertsch ed., 1981).

39 Discourse in Action: Introducing Mediated Discourse Analysis (Sigrid Norris \& Rodney H. Jones eds., 2005). In these contexts there is clearly a cultural control dynamic in place as well, however (see infra Part IV on the role of ideology in transplants). From a broader perspective one could also address the same topic from a cultural control perspective, as I intend to do in a future essay.

40 Cf. Ron Scollon \& Susan W. Scollon, Fast English, Slow Food, and Intercultural Exchanges, in IDENTITY, COMMUNITY, DisCourse 32, 35 (Giuseppina Cortese \& Anna Duszak eds., 2005).

41 Yoram Shachar, Jefferson Goes East: The American Origins of the Israeli Declaration of Independence, 10 THEORETICAL INQUIRIES L. 589 (2009). 
draft of the legal document that eventually became the Israeli Declaration of Independence was first assigned to Mordechai Beham, a minor figure in the nascent ministry of justice headed by Felix Rosenblueth in Tel Aviv in 1948. Beham was simply unable to draft a declaration of independence from scratch. He did not know where and how to begin, as he confided to his family, so he copied. The source of inspiration was found in the rich private library of Rabbi Harry Davidowitz, just across the street from where Beham's family lived. Armed with three pages of English citations, he was eventually able to produce a first draft of the document in the short time that had been assigned to him. To be sure, the final version of the Israeli Declaration of Independence proclaimed by David Ben-Gurion (as well the more advanced draft for which Rosenblueth took responsibility) cannot be considered Hebrew versions of Thomas Jefferson's Declaration of Independence:

They were, respectively, Rosenblueth's and Ben-Gurion's Declaration of Independence. And yet, they would not have been what they were if Mordechai Beham had not set pen to paper like a diligent student in a private library in Tel-Aviv and written "When in the course of human history it becomes necessary for one people ...."42

\section{Micro-MACRO II: IDEOLOGY}

The analysis of the contexts in which discourse turns into action also shows the importance of ideologies as a means conducive to the legitimization of norms, including transplanted norms. Ideologies as forms of action-oriented beliefs respond to the need to build consensus or resistance to the transplanted law. They transform power into influence.

The micro perspective on legal transplants advanced here conceives of ideology in functional terms, as a means of coordinating the actions of the members of a group, whether dominant or not. It is in the nature of ideology that its adherents will mostly act in the same way in a similar situation, show willingness to carry out joint tasks, and contribute to group cohesion. In that sense, an ideology is essentially an interface between

42 Yoram Shachar, From Divine Providence to the Rock of Israel: Two Declarations of Independence (June 11, 2008) (draft version of Shachar, supra note 41, delivered at the Cegla Center conference on Histories of Legal Transplantations, on file with author). There are countless example of this transformative dynamic, which is brilliantly illustrated on a larger scale by a recent study: MEDINA, supra note 5. 
individual practice and collective action. ${ }^{43}$ As a means of facilitating change, ideology works more smoothly when it appears to be "neutral" because it relies on assumptions that are largely unchallenged (such as those associated, for example, with the ideas of progress, modernization, development). It sells even better as an expression of paternalistic benevolence (compassionate conservatism; foreign aid). Ideology has mostly been investigated as a means of legitimizing domination. To speak of domination as God-given, natural, inevitable, etc. effectively breaks down psychological resistance to it by making any alternative seem unreal. ${ }^{44}$ And yes, lawyers have regularly engaged in arguing that domination is, under given conditions, the realization of high ideals of justice. ${ }^{45}$ Yet ideology is not always linked to a strategy of domination. Some ideologies support the status quo, others are invoked to promote reform or revolution. In the present context, ideology is therefore introduced as a methodological concept which is intended to convey neither positive nor negative connotations. Prestige is often mentioned as one of the vehicles of legal transplants. ${ }^{46}$ But the analysis of prestige as a factor in the process of legal transplantation falls into the broader domain of the analysis of ideology, since prestige is inscribed in a set of beliefs about the world, about status and achievement.

Four articles in this volume directly address various dimensions of ideology with specific regard to transplants. Christopher Tomlins explains, inter alia, how the creation of an Anglo-American law of slavery in the modern age relied on arguments that supported slavery as being just. ${ }^{47}$ Jane Dailey shows how the ideology of race superiority in the U.S. was a pillar of the prohibition against interracial marriages well after World War II, and how U.S. resistance to international human rights norms on the ground of sovereignty was related to it. ${ }^{48}$ Steven Wilf elucidates nineteenth

$43 C f$. Discourse as Social InTERACtion 25 passim (Teun A. van Dijk ed., 1997); from a similar perspective, Monateri, supra note 5, notes that comparative law itself can be considered an ideological project.

44 Tom R. Tyler, Psychological Perspectives on Legitimacy and Legitimation, 57 ANN. Rev. Psychol. 375 (2006); J. Berger et al., The Legitimation and Delegitimation of Power and Prestige Orders, 63 AM. Soc. Rev. 379 (1998).

45 See, e.g., Roland BARThes, Grammaire africaine, in Mythologies 137, 139 (1957): "DIEU: forme sublimée du gouvernement français."

46 E.g., Gianmaria Ajani, By Chance and Prestige: Legal Transplants in Russia and Eastern Europe, 43 Aм. J. CoMP. L. 93 (1995).

47 Christopher L. Tomlins, Transplants and Timing: Passages in the Creation of an Anglo-American Law of Slavery, 10 THEORETICAL INQUIRIES L. 389 (2009).

48 Jane Dailey, Race, Marriage, and Sovereignty in the New World Order, 10 THEORETICAL INQUIRIES L. 511 (2009). 
century and early twentieth century legal primitivism and its contribution to the legitimization of patterns of domination over indigenous peoples. ${ }^{49}$ He notes that cultural clichés - I would say more broadly ideologies can become technologies of power in the legal domain. ${ }^{50}$ Assaf Likhovski's history of two Israeli legal cooperation programs which unfolded in the 1950s and 1960s highlights the complicated history surrounding the development of a segment of that network of international relations that marks the birth of a new state ${ }^{51}$ As Likhovski notes, credible commitments to systems of belief may require costly investments that need to be perceived by others to produce positive responses. Conspicuous consumption - frequently associated with prestige - is one way to signal willingness to undertake and carry out such commitments. In the case analyzed by Likhovski, the new State of Israel invested in the two programs to show its willingness to cooperate with other countries and advertise its own stability and strength. The programs were designed to communicate to Israel's potential Western allies as well as its Arab enemies the fact that Israel was a part of the civilized world and intended to enjoy the benefits commonly associated with admission to the exclusive club of mature democracies, though, as Likhovski notes, considerations regarding the practical goals of these programs were also important in their making.

Ideologies are not perennial, they rise and fall. Successful ideologies are in a state of constant evolution. They adapt to changing environments. ${ }^{52}$ One of the most fecund exercises in comparative law research is the analysis of the origin and decline of ideologies, their transformations, their ambiguities, and above all, their contradictions. From the micro perspective advocated here, it is certainly true that ideologies tolerate multiple personal affiliations and subtle variations in personal commitments.

\section{Doing Justice in the Case of Transplants: An Open Issue}

Finally, the study of legal transplants from the perspective advocated here leads to reflections on issues of justice that transcend the boundaries of

49 Steven Wilf, The Invention of Legal Primitivism, 10 TeORETICAL INQUIRIES L. 485 (2009).

50 Id.

51 Likhovski, supra note 16.

52 J.M. BALKIN, CUTURAL SOFTWARE: A THEORY OF IDEOLOGY (1998) approaches this theme through the prism of meme theory analysis of cultural evolution in Darwinian terms. 
a single legal system, confronting justice with the challenge of diversity among communities and individuals.

Most theories of justice in circulation today begin with the notion of community and virtually end there. They examine what justice requires within the boundaries of the community. Whether that community is defined in political or moral terms, these theories have a hard time with questions of justice that concern those who do not belong to the community, or live at its margins. The source of the difficulty is easy to understand. These theories assume that justice and the recognition of rights are explicitly or implicitly dependent upon preexisting individual commitments that are constitutive of the community. The boundaries of the community defined by those commitments set the yardstick of justice. Those who do not belong to the community can be dealt with on a different footing. If they are not treated according to the murderous idea that might makes right, they nonetheless stand on precarious ground. In other words, if no community upholds your claims, they may very well fail. This dramatically illustrates how little "common humanity" by itself can achieve.

In the last few centuries natural law - a major intellectual attempt to develop an alternative vision of the legal order - has been relegated to the corner by the ascent of legal positivism and political realism. Furthermore, natural law has been a poor shield against the abuses carried out in the name of both philosophies. Among its limitations, there is also its ethnocentric bias, despite its universalistic claims.

In world history, transplants have been the occasion for reflections on justice that decry both the limitations of natural law and the positivistic or realist slant of much contemporary legal thought. Transplants bring into contact bodies of law which are based on different assumptions, if not even on different ontologies. ${ }^{53}$ This by itself casts doubt on the absolute validity of the normative systems that come into contact. To look to different laws with curiosity is to learn that the path of the law is not to be thought in the singular, but in the plural. This outlook undermines any abstract notion of justice and the very idea that the boundaries of community are also the boundaries of justice..$^{54}$ The growth of judicial review across the globe after World War II is an example of this kind of transplant and a major one at that,

53 Figured Worlds: Ontological ObStacles in InTERCUltural Relations (Joseph Clammer et al. eds., 2004).

54 KWAME ANTHONY APPIAH, COSMOPOLITANISM: ETHICS IN A WORLD OF STRANGERS (2007). 
as Morton Horwitz notes in his contribution to this volume on constitutional transplants. ${ }^{55}$

Legal transplants involving violence and coercion of all kinds cannot be put in the same box with peaceful transplants, however. Under tragic circumstances, justice becomes a burning issue for everyone. When transplants are carried out in tragic contexts they expose the brutal effects that the exercise of power has on the lives of those who live under the transplanted law and raise more urgent questions about what the law is. To be sure, international law today is regularly called upon to meet the challenge to justice posed by aggressions and outbursts of violence across the globe. Its origins lie in the rejection of the old idea that the law has little to say in the presence of unequal power relations. ${ }^{56} \mathrm{It}$ is beyond the scope of this Article to examine what international law has achieved in this respect, either through the discourse of human rights, or otherwise. The bottom-up perspective adopted here requires us instead to consider once more the level at which individuals who are involved in transplants imposed by violence take action and react to it. At this level, the dynamic that leads to a betrayal of justice is regularly unleashed by attacks on the moral status of the targets of violence and coercion. This strategy works to build estrangement and put distance between the perpetrators and their victims. The undoing of sentiments of empathy that support pacific coexistence thus destroys the fundaments of the common ground for equal treatment that are rooted in our innate ability to understand the intentions and emotions of others. ${ }^{57}$

In his engaging contribution to the conference upon which this issue is based, on the foreign sources of the Israeli Absentee Property Act of $1950,{ }^{58}$ Alexandre Kedar rightly notes that ethnocratic legislatures often devise systems of differentiation and construct legal categories that facilitate the application of discriminatory rules, but without openly admitting that they are resorting to discriminatory treatment. This choice is an attempt to contain

55 Morton Horwitz, Constitutional Transplants, 10 TheORETICAL INQUIRIES L. 535 (2009).

$56 C f$. Thucydides, History of the Peloponnesian War bk. V, ch. 17, at 85-113 (Charles Forster Smith trans., 1921) (the Melian dialogue).

57 For scientific evidence on these innate capabilities: Maddalena Fabbri-Destro \& Giacomo Rizzolatti, Mirror Neurons and Mirror Systems in Monkeys and Humans, 23 Physiology 171 (2008).

58 Alexandre Kedar, The British, Indian and Pakistani Sources of the Israeli Absentee Property Act of 1950 (June 12, 2008) (unpublished manuscript, delivered at the Cegla Center conference on Histories of Legal Transplantations, on file with author). See also Alexandre (Sandy) Kedar, On the Legal Geography of Ethnocratic Settler States: Notes Towards a Research Agenda, 5 CURRENT LEGAL IsSUES 401 (2003). 
the loss of reputation caused by the loss of the moral high ground, which is a consequence of such an oblique move. But the subterfuge holds up a mirror to the authors of this opaque strategy. It reveals the fear of reciprocation that motivates it. That sign of weakness, I contend, is the starting point for any further reasoning on issues of justice in similar contexts. That sentiment is an implicit admission that all the parties involved in the conflict - no matter how different their habits and opinions may be - share a common precarious condition as individuals, which raises problems that the formation of modern states has not resolved. We have to go back to the intuition of that common condition to understand why the Universal Declaration of Human Rights, just like so many other human rights instruments, is best understood not as an act of self-confidence adopted to celebrate moral progress, but as a narrow escape route from the tragic future prepared by the catastrophic past unleashed by the limitations of the Hobbesian paradigm of state sovereignty. This document, like other documents of its kind, is a testimony to the necessity to come to terms with that past in the arena of law, justice, and public discourse. We should be open to the recognition that the chances of an eventual redemption are slim if we do not attend to this need. 
